\author{
DOI 10.31558/2519-2949.2019.3.8 \\ УДК 94:329.15(477.82)“1985-1991”
}

ORCID ID: https://orcid.org/0000-0002-0464-0086

Чура В. І., Львівський національний університет імені Івана Франка

\title{
ЧИСЕЛЬНІСТЬ КОМУНІСТИЧНИХ ОСЕРЕДКІВ ЗАКАРПАТТЯ ПЕРІОДУ ПЕРЕБУДОВИ
}

Наукова розвідка розкриває причини, динаміку та наслідки зменшення чисельності комуністичних лав Закарпатського обласного комітету КПРС-КПУ у другій половині 80-х початку 90-х рр. ХХ ст. внаслідок національно-демократичного руху, що охопив регіон у зазначений хронологічний період. Започаткована компартійним керівництвом СРСР на зламі 1980-х рр. перебудова мала на меті збереження провладного статусу за правлячою КПРС, політикоекономічні засади якої зазнавали таких деформачій, приховати які було вже не можливо. У політичному аспекті вони полягали у зневірі громадян країни щэодо ідеологічної доктрини комунізму внаслідок чисельних злочинів комуністичного керівництва минулих десятирічь.

У економічному річищі деструктивні явища виражалися у перманентно низькому матеріальному становищі робітників та селян, які офіційно були задекларовані як основна державна й партійна сочіальна опора. Однак, «косметичні» реформи не тільки не вирішили вказаних проблем, але й посилили внутрішньопартійні деструктивні явища й значно ослабили комуністичний режим на місиях. Як наслідок, в УРСР відбувається швидке розгортання національно-визвольного руху, що приводить до стрімкого скорочення чисельності місчевих первинних компартійних осередків. Одним із регіонів на тлі якого декомунізаџійні прочеси розгорталися особливо помітно, були західні області Радянської України до складу яких входило багатонаиіональне Закарпаття. У першу чергу зменшення кількості комуністів охопило найбільш чисельні робітничо-селянські соиіальні верстви, щчо вагомо розмивало партійне підгрунтя й позбавляло КПРС-КПУ суспільної підтримки.

Ключовими причинами добровільного самопозбавлення членства в партії були політичні, економічні й релігійні вмотивування, які йшли в розріз із ключовими постулатами комуністичної ідеологї̈.

На основі неопублікованих архівних документів та матеріалів періодики здійснено аналіз причин низхідної динаміки чисельності комуністичних лав Закарпаття як ілюстратора стрімкого розгортання антикомуністичного руху спричиненого прагненням патріотично налаштованої української громадськості до відновлення державної самостійності України.

У Закарпатській області УРСР у 1988-1991 рр., на хвилі демократичного а згодом й національно-визвольного руху, компартійного членства добровільно позбавилось 6806 комуністів, щуо становило 14\% їх обласної кількості. Хоча у 1988 р. таких випадків офічійно не зафіксовано, у 1989 р. членських квитків за власним бажанням позбулося 76 комуністів, у 1990 p. -2 430, у 1991 p. - 4 300. Такого скорочення, особливо у робітничо-селянському середовищі, яке становило сочіальну опору правлячої партії, регіональні партійні осередки Закарпаття не знали з моменту їх створення у 1945 р. Решта членів КПРС-КПУ висловлювали пасивний протест, номінально перебуваючи у компартійних лавах, не сплачуючи членських внесків та не виконуючи партійних доручень, чим ставили себе поза партією. Цей стан слід кваліфікувати як банкрутство комуністичної доктрини у регіоні, що стало наслідком антикомуністичного руху патріотично налаштованої громадськості Закарпаття, який не в останню чергу уможливив відновлення державної самостійності Украӥни.

Ключові слова: перебудова, Закарпаття, КПРС-КПУ, демократизаџія, комуністичні осередки, чисельність, скорочення, первинні парторганізації.

Політика перебудови започаткована компартійним керівництвом СРСР у другій половині 80-x pp. XX ст. мала на меті збереження владного статусу за правлячою комуністичною партією, політико-економічні засади якої зазнавали вагомих деформацій. Тому новий Генеральний секретар М. Горбачов у 1986 р. на XXVII з'їзді КПРС наважився на часткове реформування радянської державної споруди, не торкаючись ії монопартійного політичного стрижня. У економічному аспекті воно полягало у спробі прискорення дії існуючого виробничого механізму, а згодом синтезування 
ринкових та планових методів господарювання. Однак, природна несумісність зазначеного економічного інструментарію привела до стрімкого зниження матеріального становища громадян СРСР. Як наслідок, у політичному сегменті було застосовано політреформу, проголошену у 1988 р. на XIX Всесоюзній партійній конференції, які не проводилися понад п’ятдесят років. Ї̈̈ рішення спричинили поглиблення демократизації та гласності радянського суспільства, а відтак ослабили комуністичний режим й закономірно употужнили національно-демократичний рух урегіонах країни. Це мало наслідком скорочення чисельності місцевих компартійних осередків.

Проблема причин зародження, векторів розвитку та державотворчих наслідків розгортання національно-демократичного руху в УРСР на зламі 80 - 90-х рр. ХХ ст. вже була об'єктом наукових студій як вітчизняних, так і зарубіжних дослідників. На цьому тлі виокремлюються праці таких істориків як М. Аліксієвця [1], В. Барана [2], Г. Касьянова [29], С. Кульчицького [30], О. Муравського [33], А. Русначенка [35]. Утім, питання деструктивних внутрішньопартійних процесів у середовищі комуністичних осередків, що стрімко розгорталися на відтинку між XIX Всесоюзною компартійною конференцією 1988 р. й «Актом проголошення незалежності України» 1991 р., ще залишається поза увагою наукової думки.

Тому спеціальних наукових досліджень присвячених проблемі декомунізації Закарпатської області УРСР обмаль. Однак, департизація підприємств та установ Закарпаття не в останню чергу зумовила регенерацію національної свідомості й відновлення державної незалежності України. Тому автор переслідує спробу проаналізувати причини й динаміку зменшення компартчисельності Закарпатського обкому КПРС-КПУ та його увільнення від проросійської комуністичної ідеології на тлі розгортання українського національно-демократичного руху наприкінці 1980-х - початку 1990-х pp. Джерельною базою дослідження слугуватимуть неопубліковані архівні партійні матеріали та сторінки періодичних видань тієї пори.

Партійну організацію Закарпатської області засновано 15 грудня 1945 р. [5, арк. 41]. Через сорок років іiї лави об'єднували 45841 комуніста. У 1986 р. зазначена кількість зросла до 46873 партійців, 1987 p. - до 47910 комуністів, 1988 р. - до 50009 членів КПРС-КПУ. Це 4\% населення регіону. Компартійці краю зосереджувалися у 1469 первинних, 1677 цехових парторганізаціях та 1706 партгрупах [6, арк. 53-58] під керівництвом обкому, 2 міськкомів та 13 райкомів партії [7, арк. 10]. За національним розподілом: 77,6\% - українці, $13,7 \%$ - угорці, $3,6 \%$ - росіяни, $2,3 \%$ - румуни, $0,7 \%$ - словаки, $2,1 \%$ - інші [8, арк. $73-88]$. За соціальним станом: $30,6 \%$ - робітники, $12,6 \%$ - колгоспники, 46,7\% - службовці [9, арк. 54- 56]. Вищу освіту мали 34,3\% партійців [10, арк.1 - 15]. Монолітність комуністичних рядів помітно порушилась у 1988 р. - після проголошення політичної реформи у СРСР на XIX Всесоюзній партійній конференції. У ході обговорення їі тез висловилося 23684 низових комуністів і безпартійних, котрі у п’яти з половиною тисячах зауважень піддавали гострій критиці як союзно-республіканське так і місцеве керівництво. Громадськість вимагала прийняття закону про гласність, перегляду методів інтернаціональної та ідеологічної роботи, створення комісії з національних питань, заборони райкомам нав'язування господарських рішень, п'ятирічної виборності усіх партійних посад [11, арк. 8]. На засіданні бюро обкому найбільш радикальними були В. Попович- голова виконкому Вучківської сільради Міжгірського району, В. Лолин - начальник цеху місцевої філії львівського ВО «Електрон», М. Ткач секретар парткому Бичківського лісокомбінату Рахівського району [12, арк. 2]. У постанові бюро Ужгородського міськкому від 11 березня 1988 р. щодо Заводу нестандартного обладнання йшлося про часті нарікання в трудових колективах викликані недостатньою демократизацією роботи парткому [13, арк. 30-33]. Серед 57 пропозицій членів КПРС-КПУ Мукачівського району, сказаних у ході XXVII звітно-виборної конференції, 23 стосувалися надмірного тиску керівників партійних органів та невмілого втручання у господарські справи [14, арк. 24]. Найчастіше представників первинок цікавили не плани, а реальні демократичні перетворення, позаяк лише вони могли покращити добробут рядових членів партії. Ця думка була наскрізною у словах робітника Хустського лісокомбінату О. Комарова. На сторінках місцевої районки «Ленінська правда» він радив увільнити партапарат від господарських функцій, перепрофілювавши його призначення в ідеологічну площину [31, с. 2]. Співзвучними були міркування машиніста локомотивного депо залізничної станції «Чоп» І. Іванова. 17 вересня 1988 р. він говорив на обласному пленумі, що вихідці із робітничого середовища номінально залучаються до партійних справ [15, арк. 34-35].

Як результат, ще у 1987 р. комісія партійного контролю обкому партії зафіксувала перші негативні тенденції чисельності чи не усіх парткомів області. Кількість робітничих висуванців Ужгородського, Берегівського, Перечинського, Рахівського районах змаліла на 2,1\% [16, арк. 17-18]. 
Динаміка партчисельності у Великоберезнянському, Хустському, Рахівському районах залишала бажати кращого [17, арк. 18]. У порівнянні із згаданим роком у 1988 р. кількість кандидатів у члени КПРС-КПУ зменшилася на 224 особи. 842 парторганізації Ужгорода, Мукачеве, Берегівського, Виноградівського, Тячівського районів не поповнювали партійних лав. Все списувалося на процес самоочищення ілюстрований у статтях Берегівської районки «Червоний прапор». Публікації «Краще виключити...» [37, с. 2], «Партія - не прохідний двір» переконували читачів, що низхідна кандидатська динаміка - це наслідок звільнення партії від баласту випадкових людей [38, с. 45]. Цікаво, що до Угорщини та Чехословаччини емігрувало у 1986 р. - 5 партійців, 1987 р. 13 комуністів, 1988 р. - 21 член КПРС-КПУ. У чотирьох відібрано квиток за справляння релігійних обрядів. Проте, випадків добровільного позбавлення партійності не виявлено [17, арк. 18].

Статті, що віддзеркалювали скорочення партійної чисельності у 1989 р. не часто опинялися на періодичних шпальтах. Одна 3 них на початку року потрапила на сторінки газети Тячівського райкому «Дружба». Йшлося про комічну ситуацію. Партійна організація радгоспу імені Ф. Дзержинського у кількості 2 осіб втрете не могла обрати секретаря парткому через ії кількісну невідповідність із статутними вимогами [32, с. 4]. Тоді ж завідувач організаційним відділом обкому М. Черепаня попереджав про зменшення кількості кандидатів в партію в усіх районах окрім Іршавського і Рахівського на 224 особи, або на 13,3\%. Особливо у Мукачівському, Берегівському та Воловецькому районах, де відставання від контрольних показників сягало 30,6\%.

Відбувалося зменшення кількості комуністів-росіян в Ужгородському i Мукачівському міськкомах та комуністів-угорців у Берегівському та Ужгородському райкомах. Вже системно порушувався принцип пріоритетності прийому в КПРС-КПУ робітників та селян. В Ужгороді та Мукачеве кількість робітничого поповнення змаліла на 229 осіб, або 38,1\%, у Берегівському Мукачівському, Свалявському райкомах - на $36,6 \%$. Загальна питома вага робітничо-селянського поповнення за рік скоротилася на 6,7\%. У восьми промислових, одинадцяти транспортних та п'яти будівельних парткомах число комуністів зменшилося на половину. У кожному дев'ятому цеху, кожній шостій дільниці, кожній другій бригаді та кооперативі комуністів не було як таких. В орендованих та госпрозрахункових підрозділах їх прошарок сягав 6,4\%. 3 лав КПРС-КПУ було виключено 380 партійців. На 30\% збільшилася кількість вигнанців за політичну незрілість, антипартійну поведінку та справляння релігійних обрядів.

На початку 1989 р. 11 комуністів добровільно здали партквитки, 87,5\% з яких мали двадцятирічний партійний стаж. Голова обкомівської комісії партійного контролю В. Герцянин попереджав про збільшення на 1,6\% кількості комуністів, які не бажали виконувати доручення i тому були позбавлені партійності. Найпомітніше у Тячівському районі - 31 особа, Рахівському - 16, Берегівському - 15 [18, арк. 71]. Кількість шкіл політичного навчання зменшилася від 1985 до 1116 закладів, а чисельність їх слухачів знизилася від 45 тис до 30 тис слухачів [19, арк. 19-20].

У першій половині згаданого року ще 10 комуністів повернули партквитки. Це 3 робітники, 3 колгоспники, 3 пенсіонери, 1 службовець, партстаж яких перевищував двадцять років. Двоє не погоджувалися з політикою перебудови, троє не бажали бути в лавах КПРС, котра привела країну до застою, четверо - за релігійними переконаннями [20, арк. 18-19]. Не вселяла оптимізму і друга половина року. У вересні-жовтні партійності самопозбавилося 25 осіб. В Ужгороді - 10, Мукачеве 8, Берегово, Сваляві, Тячеві і Хусті- 7. Це 13 робітників, 5 колгоспників, 7 службовців. Вісімнадцять із них перебували в партії понад чверть віку. Серед перших з партії вийшли М. Зайцев - робітник заводу «Точприлад», В. Денисов - монтер Мукачівського РВ3, В. Сокач працівник Берегівського РВС, Ю. Сотак - столяр Облрембудтресту. «Чинниками, які спонукають до виходу з партії є гострота міжнаціональних відносин та діяльність націоналістичних громадських об'єднань,» - пояснював причини добровільної здачі квитків згаданий М. Черепаня [21, арк. 63]. Загальна кількість партгруп поменшала на 90 організацій. В Ужгороді - на 18, Мукачеве - на 21, Великоберезнянському районі - на 10 [22, арк. 89]. За даними обкому від 12 грудня 1989 р. річна кількість членів КПРС, які добровільно відмовилися від партійності нарахувала 76 осіб. Серед них 40 робітників, 13 службовців, 23 колгоспники. У 55 випадках їх партстаж налічував понад 20 років. $65 \%$ відмовників вмотивовувала цей крок політичними причинами, $35 \%$ - економічними. Серед перших найпоширенішими мотивами було небажання виконувати партійні доручення та платити членські внески, серед других -низький рівень зарплат [23, арк. 10].

У 1990 р. 400 первинок (26\% загальної кількості) не прозвітували перед обкомом про збір внесків, а 299 (17\%) не здали гроші в банк. Упродовж року 4220 комуністів не сплатило внесків, 1878 з яких - за останній місяць. Лише за вересень-жовтень до партійної каси не додано 
100 тис крб. Тотальні несплати спостерігалися в Ужгородській міській (182 організації), Берегівській (45 організацій), Виноградівській (65 організацій), Свалявській (23 організації), Хустській (39 організацій), Мукачівській (18 організацій) районних осередках КПРС-КПУ. Загалом, обсяги несплати збільшилися на 46,8\% у порівнянні з 1989 р. [24, арк. 8]. 18 травня 1990 р. 37 комуністів Майданського заводу пластмас Міжгірського району одночасно написали заяви про вихід з партії. За чотири наступні місяці партійності позбавилося ще 300 осіб [25, арк. 13]. На червневій партконференції закарпатський партапарат змушений констатувати: керівники Ужгородського та Мукачівського міськкомів, Воловецького, Виноградівського, Міжгірського, Іршавського, Берегівського райкомів настільки втратили політичну ініціативу, що за півроку з партії виключено 293 осіб, а добровільно залишило іiі ряди 315 партійців [26, арк. 6-8].

У звіті обкомівського голови ревізійного комітету йшлося про небувалі розміри несплати членських внесків. 1733 комуністи не здали 4200 крб., що на 10\% більше ніж минулого року. 205 комуністів не платило коштів більш як три місяці. Найбільше неплатників було в Ужгородській міській та Перечинській, Виноградівській і Мукачівській районних парторганізаціях. Секретар парткому Виноградівської взуттєвої фабрики М. Гнетило самовільно залишив у себе 3635 крб., а партійний лідер Свалявської ПМК Р. Цанько - 2291 крб. Вони стверджували, що низові партійці не хотіли утримувати партапарат і прагнули здавали кошти лише на потреби первинки [27, арк. 2-9] . 21 лютого 1990 р. усі комуністи Закарпатської геологорозвідувальної експедиції відмовилися перераховувати кошти на обкомівський банківський рахунок. У рішенні зборів вони виступили за негайну відставку Закарпатського обласного комітету КПРС-КПУ у повному складі [28, арк. 1-10].

Загалом, у першому кварталі 1990 р. 126 комуністів добровільно здало партійні квитки, другому - 281, третьому - 597, четвертому - 1002.827 партійців не захотіли вказати причини, 230 - не бажали виконувати партійні доручення, решта вмотивовувала падінням авторитету КПРС-КПУ [20, арк. 20 - 22]. 28 грудня секретар обкому I. Мигович доповідав, що всього у зазначеному році компартійності самопозбавилося 2430 осіб. Це 1262 робітники, 750 службовців, 156 колгоспників, 226 пенсіонерів, 36 студентів, 4 партійні керівники. 915 з них налічували понад 20 років партійного стажу. 2116 відмовників не вказали причини виходу з КПРС-КПУ, решта була не задоволена повільним розгортанням перебудови [20, арк. 23 - 24]. Ключову причину компартійного розпаду розкривав аналіз розлогої статті «Не бажаю бути комуністом», опублікованої на шпальтах газети Берегівського райкому «Червоний прапор». Головним вмотивуванням позбавлення партійності була причина вказана у заяві робітниці Радіозаводу К. Петровцій. «Не вірю у правильність політики КПРС,»- писала вона [40, с. 1]. Якщо зимою 1991 р. керівник мукачівських комуністів 3. Лєндєл заявляв: скорочення компартійних лав - це процес самоочищення від зрадників комуністичних принципів, то влітку тячівська районна газета «Дружба» помістила статтю «Як би тільки самоочищення». Ї̈̈ автор заступник директора радгоспу імені Леніна П. Коршинський зазначав: «Втрата чверті складу парторганізації - симптом тривожний. Пояснювати даний процес самоочищенням - безглуздо. Тут пряма зневіра робочої людини до вчорашніх ідеалів» [32, с. 4].

Тому у 1991 р. кількість членських внесків змаліла на 1,5 млн. крб. В Ужгородській та Мукачівській міських, Берегівській i Мукачівській районних парторганізаціях понад 300 парторгів, або 35\% їх загальної кількості не звітували перед обкомом щодо перерахованих сум. Не платили внесків 2720 комуністів, 1388 яких - понад півроку [22, арк. 89] . Станом на 1 квітня 311 парторганізацій (20,5\% їх обласної кількості) не доповідали про виручені суми, 282 - не здавали кошти до банку. Загалом, не розрахувалися із партією 2909 комуністів: в Берегівському райкомі не сплатило 62,1\% членів КПУ, Хустському - 53,5\%, Іршавському 50,6\%, Воловецькому - 30,7\%, Свалявському - 9,4\%. Кількість неплатників ужгородських ПМК, тресту «Курортрембуд», Монтажного управління, Інспекції держстраху, об'єднання «Закарпатсервіс», мукачівських Заводу керамічної плитки і ШЕД, Виноградівського комбінату комунальних підприємств доходила до 90\%. За три місяці 1991 р. до партійної скарбниці не потрапило 107 тис. крб., або 47,6\% [26, арк. 9- 10]. До 1 липня не розрахувалося ще 308 парткомів: в Ужгороді- 72, Мукачеве - 62, Берегово - 30, Рахові - 18, Сваляві - 16. Боржниками залишалося 3196 комуністів, або 7,3\% їх загальної кількості [26, арк. 9-10].

Партійні лави Ужгородського міськкому втратили 8\% членів, Мукачівського - 9,6\%, Міжгірського райкому - 15,6\%, Перечинського - 9,9\%, Рахівського - 8,7\% [23, арк. 10]. 3 партії вийшло 386 членів керівного господарського складу області. Серед них - 21 перший 
керівник [22, арк. 89]. Напередодні обласної партконференції партію покинули 18 делегатів - знаних комуністів області. Це І. Бабинець, В. Баранюк, А. Івегеш, А. Орбан, Ю. Чейпеш, В. Янковський. В. Данюк, Г. Гонак, М. Капац та член обкому М. Юхимович [21, арк. 63]. Позбавився партійності другий секретар Ужгородського райкому А. Гуцул [23, арк. 10]. У Перечинському районі партійні лави покинула 21 особа керівного складу[24, арк. 8]. Припинила діяльність партійна організація філії львівського ВО «Електрон» у Міжгірському районі [25, арк. 13]. Загалом, за перше півріччя 1991 р. комуністичної приналежності позбавилося 4,3 тис. осіб, або 7,3\% членів КПУ. Серед них $43 \%$ робітників, $37,6 \%$ - службовців, $9 \%$ - селян, $10,3 \%$ - пенсіонерів. $50 \%$ не пояснювали причин, $20 \%$ були незгідними із політикою партії, $16 \%$ не бажали платити внески, $2 \%$ перейшли у національні партії [25, арк. 13].

Таким чином, у багатонаціональній Закарпатській області УРСР упродовж 1985-1991 перебудовних років, внаслідок демократизаційного та національно-визвольного руху українського народу, компартійного членства добровільно самопозбавилося 6806 осіб, що становило 14\% обласної кількості членів партії. Хоча у 1985-1988р. таких випадків офіційно не зафіксовано, у 1989 р. комуністичної приналежності за власним бажанням позбулося 76 осіб, у 1990 р. - 2430, у 1991 p. - 4 300. Ключовими причинами такого кроку спочатку була незгода із повільним розгортанням перебудови, яка поступово переросла у несприйняття компартійної доктрини, що значно активізувало антикомуністичний, а згодом й державотворчий рух.

Особливо помітно скорочення комуністичних лав спостерігалося серед багатолітніх комуністів - вихідців із робітничо-селянського середовища, яке становило соціальну опору правлячої партії. Це відчутно розмивало іï суспільне підгрунтя й спричиняло припинення діяльності у першу чергу первинних організацій. Звертає на себе наукову увагу те, що решта членів регіональних осередків КПРС-КПУ Закарпаття висловлювали пасивний протест, номінально перебуваючи у компартійних лавах, не сплачуючи членських внесків та не виконуючи партійних доручень, чим ставили себе поза партією. Отже, зазначені внутрішньопартійні корозійні процеси слід кваліфікувати як банкрутство проросійської комуністичної влади, котрі були результатом багатовікового генетичного прагнення української патріотично налаштованої громадськості регіону до відновлення державної самостійності України.

\section{Бібліографічний список:}

1. Аліксієвець М. Тернопілля: сторінки історії. Тернопіль, ТДПІ, 1995. 161 с.

2. Баран В. Україна: новітня історія (1945-1991рр.). Львів, Інститут українознавства імені І. Крип'якевича НАН України, 2003. 670 c.

3. Гужва I. Хто першим тікає з корабля? // Вісті Ужгородщини. 1991. 28 березня. С. 2.

4. ДАЗО (Державний архів Закарпатської області». Ф. 1. (Закарпатський обком Компартії України).

Оп. 30. Спр. 19. Арк. 11-27.

5. ДАЗО. Ф. 1. Оп. 30. Спр. 22. Арк. 41.

6. ДАЗО. Ф. 1. Оп. 30. Спр. 83. Арк. 53-58.

7 .ДАЗО. Ф. 1. Оп. 30. Спр. 85. Арк. 10.

8. ДАЗО. Ф. 1. Оп. 30. Спр. 90. Арк. 73-88.

9. ДАЗО. Ф. 1. Оп. 30. Спр. 125. Арк. 54-56.

10. ДАЗО. Ф. 1. Оп. 33. Спр. 34. Арк. 1-15.

11. ДАЗО. Ф. 1. Оп. 33. Спр. 40. Арк. 8.

12. ДАЗО. Ф. 1. Оп. 33. Спр. 60. Арк. 2.

13. ДАЗО. Ф. 1. Оп. 33. Спр. 73. Арк. 30-33.

14. ДАЗО. Ф. 1. Оп. 33. Спр. 80. Арк. 24.

15. ДАЗО. Ф. 1. Оп. 33. Спр. 85. Арк. 34-35.

16. ДАЗО. Ф. 1. Оп. 34. Спр. 1. Арк. 17-18.

17. ДАЗО. Ф. 1. Оп. 34. Спр. 9. Арк. 18.

18. ДАЗО. Ф. 1. Оп. 34. Спр. 17. Арк. 71.

19. ДАЗО. Ф. 1. Оп. 34. Спр. 69. Арк. 19-20.

20. ДАЗО. Ф. 1. Оп. 34. Спр. 82. Арк. 18-19.

21. ДАЗО. Ф. 1. Оп. 36. Спр. 1. Арк. 63.

22. ДАЗО. Ф. 1. Оп. 36. Спр. 4. Арк. 89.

23. ДАЗО. Ф. 1. Оп. 36. Спр. 13. Арк. 10.

24. ДАЗО. Ф. 1. Оп. 36. Спр. 20. Арк. 8.

25. ДАЗО. Ф. 1. Оп. 36. Спр. 26. Арк. 13.

26. ДАЗО. Ф. 1. Оп. 36. Спр. 44. Арк. 6-8.

27. ДАЗО. Ф. 9. Оп. 46. Спр. 24. Арк. 2-9. 
28. ДАЗО. Ф. 13. Оп. 47. Спр. 26. Арк. 1-10.

29. Касьянов Г. В. Незгодні: українська інтелігенція в русі опору 1960 - 80-х років. Київ : Либідь, 1995. $224 \mathrm{c}$.

30. Кульчицький С. В. Історичні передумови переростання перебудови в національну революцію (19891991) // Проблеми історії України: факти, судження, пошуки: Міжвідомчий збірник наукових праць. Інститут історії України НАН України. 2001. № 5. С. 330-351.

31. Комаров О. Чи можна без адміністрування. // Ленінська правда. 1988. 16 червня. С. 2.

32. Коршинський. П. «Як би тільки «самоочищення». // Дружба. 1991. 12 липня. С 4.

33. Муравський О. Західні землі України: шлях до незалежності (1985-1991). Львів Інститут

українознавства ім. І. Крип'якевича НАН України, 2011. 268 с.

34. Ленінська правда. 1988. 25 грудня. С. 2.

35. Русначенко А. Національно-визвольний рух в Україні середина 1950-х-початок 1990-х рр. Київ. Видавництво імені Олени Теліги, 1998. 720 с.

36. Нариси історії Закарпатської обласної партійної організації. Ужгород, 1980. 320 с.

37. Папіш М. ...Не бажаю бути комуністом! // Червоний прапор. 1990. 25 січня. С 2.

38.Тимофєєв В. Партія - не прохідний двір. // Червоний прапор. 1988. 2 серпня. С. 45.

39.Тимша М. Первинна в застої. // Дружба. 1989. 17 січня. С. 2.

40.Червоний прапор. 1988. 21 липня. С. 1.

41.Червоний прапор. 1990. 27 грудня. С. 4.

\section{References:}

1. Aliksiievets M. Ternopillia: storinky istorii. Ternopil, TDPI, 1995. $161 \mathrm{~s}$.

2. Baran V. Ukraina: novitnia istoriia (1945-1991 rr.). Lviv, Instytut ukrainoznavstva imeni I. Krypiakevycha NAN Ukrainy, 2003. $670 \mathrm{~s}$.

3. Huzhva I. Khto pershym tikaie z korablia? // Visti Uzhhorodshchyny. 1991. 28 bereznia. S. 2.

4. DAZO - Derzhavnyi arkhiv Zakarpatskoi oblasti. F. 1. Op. 30. Spr. 19. Ark. 11-27.

5. DAZO. F. 1. Op. 30. Spr. 22. Ark. 41.

6. DAZO. F. 1. Op. 30. Spr. 83. Ark. 53-58.

7. DAZO. F. 1. Op. 30. Spr. 85. Ark. 10.

8. DAZO. F. 1. Op. 30. Spr. 90. Ark. 73-88.

9. DAZO. F. 1. Op. 30. Spr. 125. Ark. 54-56.

10. DAZO. F. 1. Op. 33. Spr. 34. Ark. 1-15.

11. DAZO. F. 1. Op. 33. Spr. 40. Ark. 8.

12. DAZO. F. 1. Op. 33. Spr. 60. Ark. 2.

13. DAZO. F. 1. Op. 33. Spr. 73. Ark. 30-33.

14. DAZO. F. 1. Op. 33. Spr. 80. Ark. 24.

15. DAZO. F. 1. Op. 33. Spr. 85. Ark. 34-35.

16. DAZO. F. 1. Op. 34. Spr. 1. Ark. 17-18.

17. DAZO. F. 1. Op. 34. Spr. 9. Ark. 18.

18. DAZO. F. 1. Op. 34. Spr. 17. Ark. 71.

19. DAZO. F. 1. Op. 34. Spr. 69. Ark. 19-20.

20. DAZO. F. 1. Op. 34. Spr. 82. Ark. 18-19.

21. DAZO. F. 1. Op. 36. Spr. 1. Ark. 63.

22. DAZO. F. 1. Op. 36. Spr. 4. Ark. 89.

23. DAZO. F. 1. Op. 36. Spr. 13. Ark. 10.

24. DAZO. F. 1. Op. 36. Spr. 20. Ark. 8.

25. DAZO. F. 1. Op. 36. Spr. 26. Ark. 13.

26. DAZO. F. 1. Op. 36. Spr. 44. Ark. 6-8.

27. DAZO. F. 9. Op. 46. Spr. 24. Ark. 2-9.

28. DAZO. F. 13. Op. 47. Spr. 26. Ark. 1-10.

29. Kasianov H. V. Nezghodni: ukrainska intelihentsiia v rusi oporu 1960 - 80-kh rokiv. Kyiv : Lybid, 1995. $224 \mathrm{~s}$.

30. Kulchytskyi S. V. Istorychni peredumovy pererostannia perebudovy v natsionalnu revoliutsiiu (1989-1991)

// Problemy istorii Ukrainy: fakty, sudzhennia, poshuky: Mizhvidomchyi zbirnyk naukovykh prats. Instytut istorii Ukrainy NAN Ukrainy. 2001. № 5. S. 330-351.

31. Komarov O. Chy mozhna bez administruvannia. // Leninska pravda. 1988. 16 chervnia. S. 2.

32. Korshynskyi. P. «Iak by tilky «samoochyshchennia». // Druzhba. 1991. 12 lypnia. S 4.

33. Muravskyi O. Zakhidni zemli Ukrainy: shliakh do nezalezhnosti (1985-1991). Lviv Instytut ukrainoznavstva im. I. Krypiakevycha NAN Ukrainy, 2011. $268 \mathrm{~s}$.

34. Leninska pravda. 1988. 25 hrudnia. S. 2.

35. Rusnachenko A. Natsionalno-vyzvolnyi rukh v Ukraini seredyna 1950-kh-pochatok 1990-kh rr. Kyiv.

Vydavnytstvo imeni Oleny Telihy, 1998. $720 \mathrm{~s}$.

36. Narysy istorii Zakarpatskoi oblasnoi partiinoi orhanizatsii. Uzhhorod, 1980. $320 \mathrm{s.}$ 
37. Papish M. ...Ne bazhaiu buty komunistom! // Chervonyi prapor. 1990. 25 sichnia. S 2.

38. Tymofieiev V. Partiia - ne prokhidnyi dvir. // Chervonyi prapor. 1988. 2 serpnia. S. 45.

39. Tymsha, 1989 - Tymsha M. Pervynna v zastoi. // Druzhba. 1989. 17 sichnia. S. 2.

40. Chervonyi prapor. 1988. 21 lypnia. S. 1.

41. Chervonyi prapor. 1990. 27 hrudnia. S. 4.

\section{Chura V. I., Number of communist transcarpathian centers in the repestroika period}

Scientific intelligence reveals the causes, dynamics and effects of the reducing of number of Transcarpathian Regional Committee of the CPSU-CPU communist ranks in the second half of the 80's early 90 's of the twentieth century as a result of the national-democratic movement which covered the region in the specified chronological period. The perestroika policy was initiated by the Communist Party leadership of the USSR at the turn of the 1980s. and was aimed at preserving the pro-government status of the ruling CPSU, the political and economic foundations of which were subject to such deformations, which was already impossible to conceal. In the political aspect, this was manifested in the concern of the country's citizens about the ideological doctrine of communism as a result of numerous crimes of the communist leadership of the past decades. In the economic flow destructive phenomena were expressed in the permanently low material situation of workers and peasants, which were formally declared as the main state and party social support. However, reforms of the restructuring not only did not solve these problems, but also intensified intra-party destructive phenomena and significantly weakened the communist regime on the ground. As a result, in the Ukrainian SSR is rapidly expanding the national liberation movement, which leads to a sharp reduction in the number of local primary communist party cells. One of the regions on the background of which decommunization processes were particularly prominent were the western regions of Soviet Ukraine, which included the multinational Transcarpathia. In the first place, the reduction of the number of Communists covered the most numerous workers and peasants social strata, which vigorously eroded the party ground and deprived the CPSU-KPU of public support. The key causes of voluntary selfdeprivation of membership in the party were political, economic and religious motivations that went against the key postulates of communist ideology.

Scientific novelty lies in the fact that for the first time in historiography based on unpublished archival documents and periodical materials has been made analysis of causes of the downward dynamics of the number of Transcarpathian communist centers as an illustrator of the rapid deployment of the anticommunist movement caused by the desire of the patriotically-minded Ukrainian public to restore the state's independence of Ukraine.

In the Transcarpathian region of the Ukrainian SSR in 1988 - 1991, on the wave of a democratic, and later, national liberation movement, Communist Party membership voluntarily deprived 6,806 communists, which was 14\% of it's regional number. Although in 1988 such cases were not officially recorded, in 1989, 76 members of the Communist Party voluntarily lost their membership tickets, in 1990 - 2,430, in 1991 4,300. Such a reduction, especially in the working-peasant environment, which was a social base of the ruling party, the regional party cells of Transcarpathia did not know since its creation in 1945. The remaining members of the CPSU-CPU expressed a passive protest, nominally being in the Communist Party, not paying membership dues and not fulfilling party orders, as they put themselves outside the party. This condition should be classified as a bankruptcy of communist doctrine in the region, which was the result of the anti-communist movement of the patriotic-minded people of Transcarpathia, which in the last resort made it possible to restore the state independence of Ukraine.

Key words: perestroika, Transcarpathia, CPSU-KPU, democratization, communist centers, number, reduction, primary party organizations. 